\title{
Housing Market Renewal in an era of new housing supply
}

\author{
Ed Ferrari* \\ University of Sheffield
}

\begin{abstract}
In the UK, New Labour's housing policy appears to have moved into a new phase. A concern with new housing supply has supplanted a previous focus on renewal and regeneration. This calls into question the continued relevance of large scale renewal programmes such as Housing Market Renewal (HMR). This paper briefly reviews the rationale for setting up the HMR Pathfinders and charts some aspects of their progress since 2003. Positive signs of change are apparent throughout HMR areas, although whether this can be ascribed to Pathfinder activity is unclear. Some of the reasons for market change are undoubtedly related to wider changes in the market, notably the rapid growth of speculative investment activity. The paper concludes that, while, superficially, HMR may now appear incongruous with the new focus on housing supply, there is insufficient evidence that lasting change in low demand markets has yet been brought about and that consequently the premature scaling back of the programme would be ill-advised.
\end{abstract}

Key words: Housing Market Renewal, housing policy, housing supply.

\section{Introduction}

In its ten-year run in government, the Labour Party in Britain has transformed the focus of housing policy not once, but twice. If the early years marked a concern with the renewal of housing, it is clear that we are now entering a period marked by an overriding concern with new housing supply. This raises important questions about the future of renewal activity and regeneration programmes such as Housing Market Renewal (HMR).

The government's tacit acceptance of the market reforms ushered in by Margaret Thatcher's iconic privatisation policies meant that its initial focus naturally fell upon those people and places left behind by those reforms: those without choice or resources. A concern with the 'socially excluded' became one of the early defining characteristics of early New Labourism. Thus it was that the incoming Prime Minister Tony Blair made the first speech of his prime ministerial career on the Aylesbury Estate 
in Southwark, in so doing launching the Social Exclusion Unit. In this speech, alongside pledges to reduce educational failure, anti-social behaviour and discrimination, Blair highlighted a 'desperate need for urban regeneration' (Blair, 1997). Urban blight and poor housing conditions - hand in hand with social problems - helped to define New Labour's domestic policy focus. This was the first transformation: renewal - not only of society, but of its houses and urban spaces. This transformational agenda of renewal led directly to such various policies and programmes as urban renaissance (UTF 1999), Decent Homes (DETR 2000), the National Strategy for Neighbourhood Renewal (SEU 2001) and, of course, Housing Market Renewal (ODPM 2003). The latter, in particular, has signalled both an acceptance of the dominance of the market in housing provision as well as a will to intervene in its operations as necessary.

The second, more recent, transformation has arguably engendered a more explicit focus on the economy and the challenges posed by an unbroken run of economic growth. Housing policy has changed in language and focus. The concern with renewal appears to have receded, to be replaced by a more prevalent discourse on 'growth': Growth Areas, New Growth Points, and culminating in the most recent housing Green Paper (CLG 2007a), with its unremitting focus on increasing the supply of new housing. The Brown government's aspiration to provide an additional three million homes by 2020 represents a significant increase over and above already-contentious housebuilding targets and has been accompanied by some 'hard talk' from the department of Communities and Local Government (CLG) in terms of building on floodplains and questioning the sanctity of green belt land.

These transformations reflect the changing fortunes of the housing market in Britain. In the mid to late 1990s memories of the last housing market crash - and the subsequent economic recession - were still fresh. Practitioner concern then reflected the problems of letting and selling properties in a 'low demand' market, especially in the industrial towns and cities of the Midlands and North. Now, towards the end of the first decade of the 2000s, it is clear that such demand difficulties are no longer the daily anxiety of housing professionals. Instead quite the opposite is true. High rates of house price inflation in relation to incomes have led to significant problems of poor affordability, a phenomenon that appears to have left no corner of the country untouched. In 1997, all of England's regions had an average lower-quartile house price-to-earnings ratio (the government's preferred measure of affordability) of around 3-4 times. By 2006, the England average stood at around 7 times, ranging from 5 times in the North East to over 8.5 times in London and the south (NHPAU 2007).

So what of the concern with renewal? Has the market solved the problems of poor housing, low values and urban blight of its own accord? Where next for HMR? This paper is particularly concerned with this latter question. The 2007 Green Paper has not ignored HMR but it promises that changes are due. Although they were set up for a 10-15 year programme, it hints that some of the areas within Pathfinder boundaries may no longer require intervention. The eventual outcome of the recent Comprehensive Spending Review will inevitably provide greater clarity in the matter. It is salient at this point to return to the original rationale for the programme; to look at the changes in markets since then; and to broadly assess whether there is still a need for a wide-ranging policy of market renewal.

In attempting to make such an assessment, this paper is structured as follows. First, the basis for the genesis of the programme - its evidence base - is revisited and an effort is made to clarify what the original objectives of HMR were. Some evidence from a recent study the author has completed for the evaluation of HMR is drawn upon to examine how the Pathfinders are doing against these objectives. Second, it is clearly necessary to examine what has changed since HMR's inception in 2002/3. The changing nature of the housing market 'problem' is examined. Third, the imperative for 
a changing emphasis for renewal activity is explored, based on how the strategic framework for HMR has changed, and its objectives have been reoriented. Finally, the question of whether HMR is still relevant in an era of poor affordability and new housing supply is addressed.

\section{The rationale for HMR}

Much of the basis of need for the HMR programme revolved around the concept of the risk of low demand (Cole \& Nevin 2004). Academic and policy research in the late 1990 s identified a range of factors which, when coincident in local areas, seemed to explain the weakness of the local housing market. The resulting 'risk' was found to be significantly higher in the North of England and within the older industrial conurbations. Around 30 per cent of the population in the North East and 26 per cent in the North West lived in a neighbourhood at risk of low demand in 2001 (Leather et al. 2007). This was approximately ten times the proportion considered at risk in London and the South East. Economic and population change was the backdrop to this, providing a broad macro-geographical context that exposed vulnerable places to risk. The regional economic differentials highlighted by Webster's (1998) and Turok \& Edge's (1999) work resonate with Holmans \& Simpson's (1999) analysis of regional migration patterns. Various commentators then pointed to myriad manifestations of the low demand problem and their implications, including ongoing processes of social housing 'residualisation' (Murie et al. 1998); changing land use and decentralisation (Nevin et al. 2000); urban blight and poor quality public services (Power \& Mumford 1999); poverty and deprivation (Lee \& Murie 1997; Burrows \& Rhodes 1998); the organisational mindset of housing agencies (Cole et al. 1999); and neighbourhood stigmatisation and insecurities (Wood \& Vamplew 1999). In their major study of low demand, Bramley et al. (2000) drew attention to the 'high level of potential accessible choice for households in low demand areas' (p. 78), referring to what they described as excess land supply and private housebuilding. Nevin et al.'s (2000) study of the 'M62 corridor' supported this, while focusing on neighbourhood coalescences of worklessness, old age, and a housing stock that was over-represented by unpopular flats, terraces and social rented units.

If these were the causes, the symptoms were even easier to identify: empty properties, low or falling housing prices, and (for the social rented sector) high rates of turnover and refused offers to let. Improvements in these indicators more or less constitute the government's own success criteria for HMR, as articulated in its plan for housing to 2010, Homes for All (ODPM 2005). They also form the basis for ongoing monitoring of the outcomes of the programme.

While not formally reflected in the above criteria, there was also acceptance that housing markets reflect the connectivity of places. One of the compelling reasons for HMR 'thinking big' and being more than a neighbourhood-focused supply-side intervention was that by taking a sub-regional perspective on market conditions it could take better account of how the market responded to intervention. This was a deliberate attempt to control for the phenomenon of displacement, where policy and investment in one area might simply encourage the problem being tackled to move elsewhere and so to shift beyond the reach of intervention. The sorts of connections between places that determine housing market influence include functional connections, such as patterns of migration (Jones et al. 2004) or commuting and economic flows between areas (Pike at al. 2006). At a structural level, the diagnosis of housing market problems is normally associated with a problematic imbalance in these connections and flows. Most Pathfinder areas, for example, witnessed severe depopulation in the last few decades of the $20^{\text {th }}$ Century. Manchester and Liverpool 
Pathfinder areas lost some 8 per cent and 10 per cent respectively of their population between 1991 and 2001 (Leather et al. 2007), as residential patterns continued to mirror a changing economic geography: jobs became much more decentralised and industry much less dependent on the specificities of place. Housing market renewal strategies are built on the need to reverse these trends by providing a more attractive residential 'offer' that, in turn, will enhance the sustainability of attempts at economic regeneration.

\section{Progress to date}

Pathfinders are approaching the end of their fifth programme year. Although many of their interventions cannot be expected to fully impact on the housing market for some years to come, it is appropriate to take stock of the progress that has been made in tackling the problems of empty properties, low house prices, turnover and outmigration.

Measuring the impact that Pathfinders have had on migration and commuting patterns is very difficult, although it is possible to draw some general conclusions. In some areas there is evidence of positive change, as the net balance of migration reverses, or at least the imbalances become less severe. But a very resonant note of caution must be rung: the data showing these changes relate to entire local authority areas and thus include the major city centres that are adjacent to many of the Pathfinder areas. The effects of urban renaissance and the residential re-densification of cities over the last decade cannot be separated out from the effects of housing market renewal.

Another strand of the rationale for housing market renewal was the prevalence of empty and unused residential property. The problems of outright abandonment were perhaps never as severe as in the North American context (although the worry was real: see Keenan et al. 1999). Vacancy rates in comparable US cities in 2000 frequently exceeded one in ten properties: Baltimore (13.7 per cent), Pittsburgh (11.5 per cent), Cleveland (11.4 per cent) and Detroit (10.2 per cent) were among the most afflicted of the USA's ex-industrial cities (HUD 2007). Areas of significant market weakness in England were also characterised by high vacancy rates, if not as high as in the US. Indeed, it was the government's inquiry into the problem of empty homes (HC 240-I, 2002), which found evidence of over 750,000 such properties in England in 2000, that prompted the establishment of a Housing Market Renewal Fund. Some improvement in the empty homes situation has been apparent since the HMR programme was set up. In 2002, local authority areas with Pathfinders had an average vacancy rate of 5.2 per cent, compared with the England average of 3.4 per cent (Leather et al. 2007). Last year, the same Pathfinder areas had an average of 4.4 per cent, significantly closer to the England average of 3.1 per cent (Figure 1). But, again, it is difficult to disentangle these crude averages from the outcomes of other processes. Interestingly, many cities are growing increasingly anxious about very high vacancy rates in their renascent city centres: Sprigings et al. (2006) note the importance of speculative activity in explaining high vacancy rates in city centres. Their paper cites evidence in Liverpool of around 13 per cent vacant city centre dwellings, although anecdote would suggest that this may be a conservative estimate. Recently, DTZ (2007) found at least 6.5 per cent of similar properties in Sheffield had been empty for over six months and that vacancy rates in some schemes were as high as 50 per cent. Emptiness in these very different parts of the market will distort district-wide averages. 
Figure 1: Vacancy rate 2001-2006

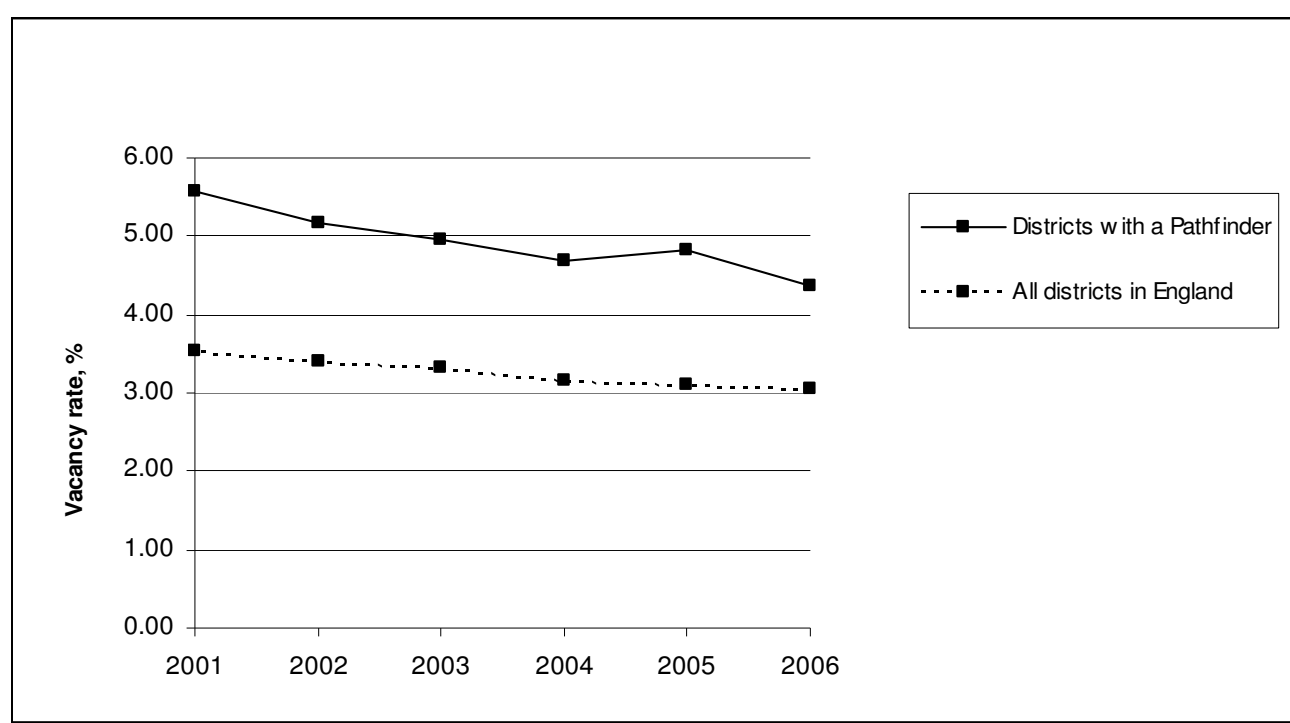

Source: CLG Housing Strategy Statistical Appendices (HSSAs)

Note: 'Districts with a Pathfinder' excludes the East Riding of Yorkshire because only a very small proportion of that district falls within a Pathfinder.

House prices in many Pathfinder areas have risen substantially. Over the last few years, rates of growth have even outstripped other parts of the market (Figure 2). However, this may merely reflect a degree of 'catching up' as the cyclical operation of the market means that Northern cities and, within them, lower price neighbourhoods tend to lag London and the south. Indeed, significant price differentials between Pathfinder areas and elsewhere remain (Figure 3) and it is the Audit Commission's view that, in relation to prices, "the available data does not support the view that pathfinder intervention is no longer justified' (Audit Commission, 2006, p. 16). 
Figure 2: Annual growth rate in median house sale price (all property types)

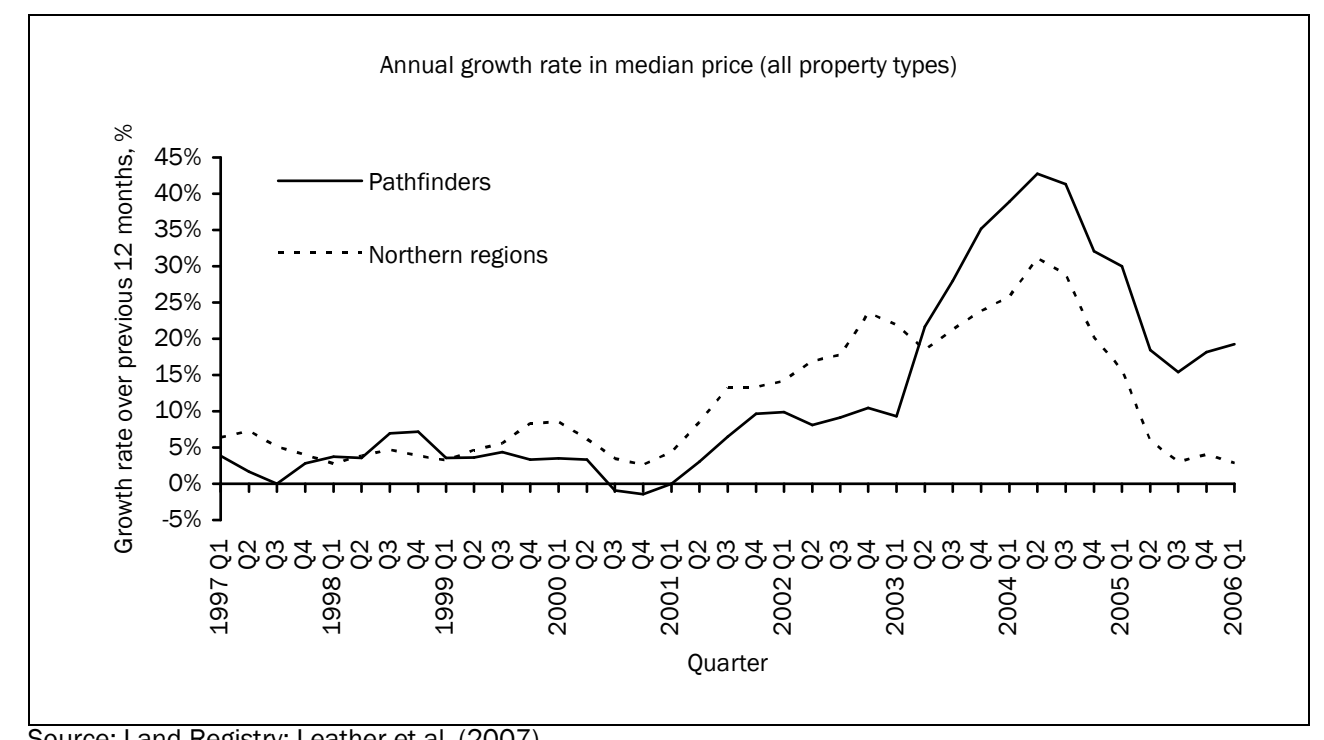

Source: Land Registry; Leather et al. (2007)

Figure 3: Median house sale price (all property types)

Median house sale price (all property types)

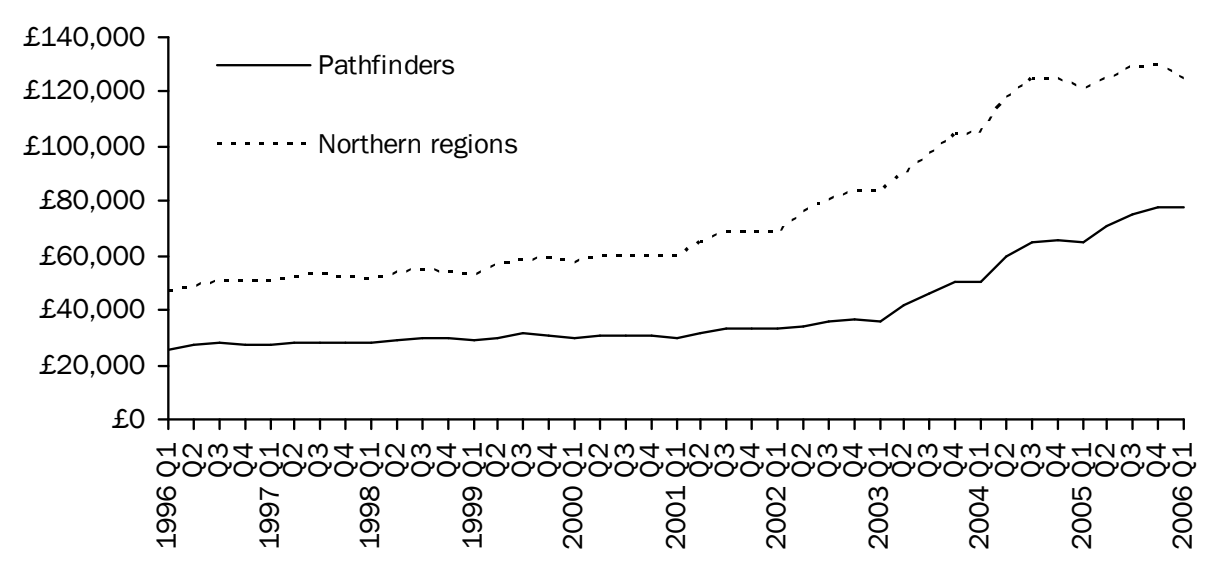

Source: Land Registry; Leather et al. (2007)

Most local authorities with a Pathfinder report that the incidence of low demand in their area has been decreasing (Figure 4). This measure, which includes an assessment of various demand indicators, suggests that turnover has been stabilising, the incidence of refused offers for social housing has been decreasing and waiting lists have lengthened. In addition to any impacts that the Pathfinders may be having, such improvements are likely to be a direct consequence of worsening affordability as securing alternative accommodation in the private sector becomes more difficult. Whether these improvements are indicative of a long term reversal of 'low demand' remains in question for two reasons. First is that the first round of HMR spending tended to focus on the clearance of the most unpopular social rented housing, as 
existing housing projects were incorporated into Pathfinder programmes. Second, is that the widespread adoption of Choice Based Lettings mechanisms has improved allocative efficiency and widened accessibility in the social rented sector (Pawson et al. 2006).

Figure 4: Local authority estimates of social rented properties in low demand

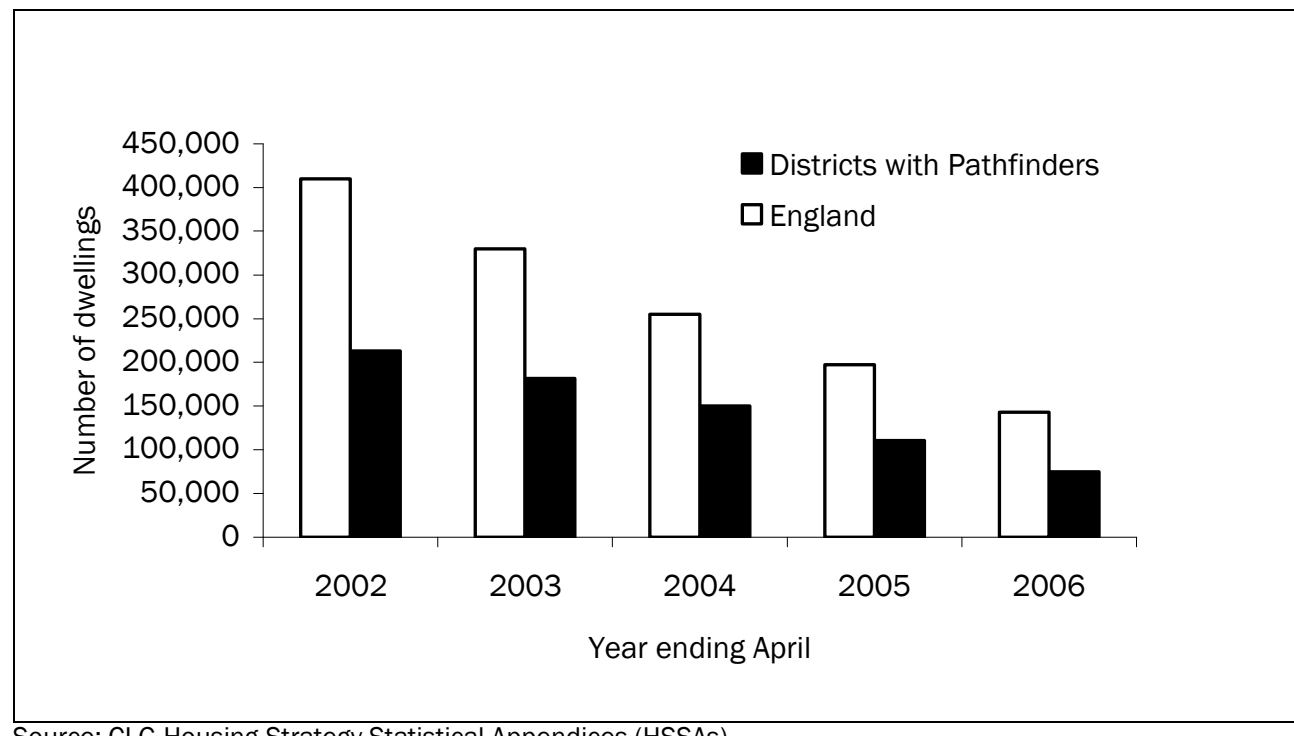

Source: CLG Housing Strategy Statistical Appendices (HSSAs).

Note: 'Districts with a Pathfinder' excludes the East Riding of Yorkshire because only a very small proportion of that district falls within a Pathfinder.

\section{A changing backdrop: the era of new housing supply}

For around three years, the housing and planning systems have been gearing up to deliver a 'step change' in housing supply. Precipitating such change has been a deep concern with house price inflation, which since 1992 has averaged 7.4 per cent per annum in the UK (Figure 5), a rate considerably higher than in other Western European countries. The Barker Review of Housing Supply (Barker 2004) concluded that "higher and more responsive levels of housebuilding, leading to a lower trend in real house prices, would benefit the UK in economic terms' (p. 11). 
Figure 5: House price inflation in the United Kingdom, 1980-2006

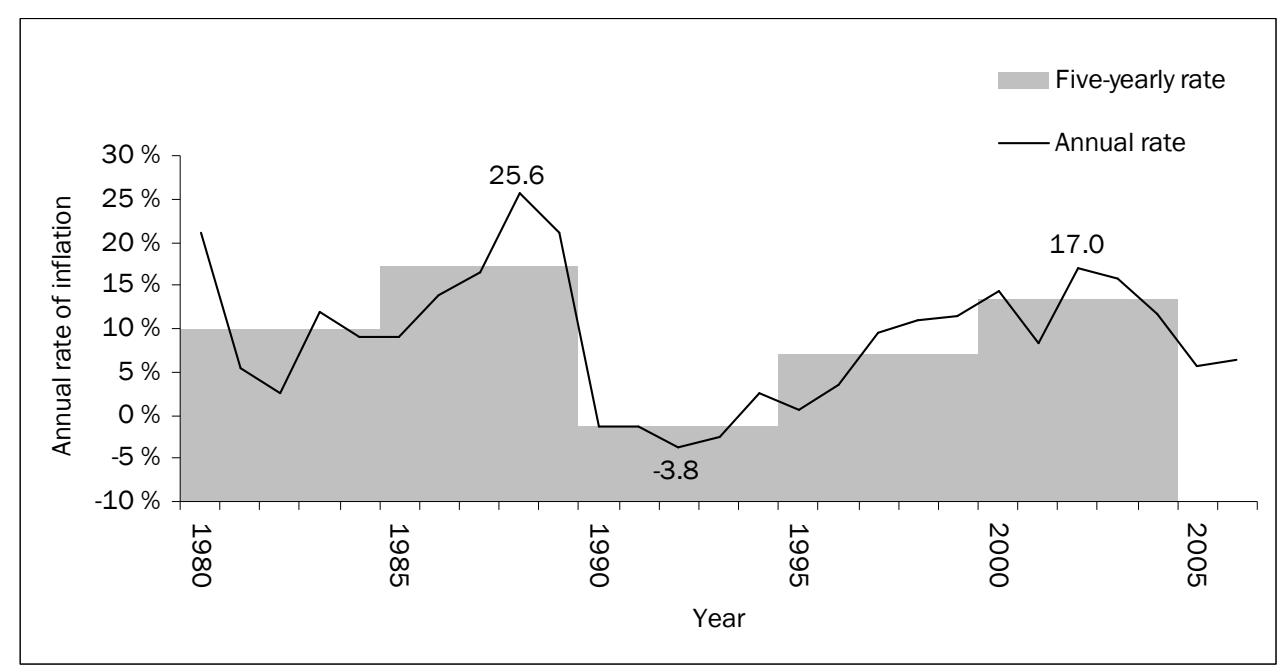

Source: CLG Live Table 502.

Note: Data are mix adjusted but are from different sources as follows. 1980-92: 5\% survey of building societies; 1993-2003: 5\% survey of mortgage lenders; 2003-04: survey of mortgage lenders; 2005-06: Regulated Mortgage Survey.

Revised planning policy guidance for housing, PPS 3 (CLG 2007b), is explicitly designed to enable the planning system to become a more pro-active agent in the delivery of new housing. Furthermore, it is clear that the government views housing policy of some importance, to the extent that the Minister for Housing has been granted a chair at the Cabinet table for the first time in recent history. The recent Green Paper is unremittingly forthright about the need for new housing supply, putting flesh on a range of policy options that include speeding up planning, freeing local authorities from some of the constraints they have faced as developers of social housing, commandeering more publicly-owned land for housing, and proposing new settlements and urban extensions.

In this context, HMR appears to lie uneasily. The programme was conceived of as a means of restructuring housing supply where there was deemed to be - crudely - an oversupply. Following on from this, then, it included significant demolition as part of its toolbox of remedial options. It has been this aspect of HMR that has proved most contentious, to the extent that HMR has been characterised as first and foremost a 'clearance programme' by local communities and heritage conservators alike. The perversities of a demolition programme in a market which is, by common understanding, overheating due to excess demand are not lost on a public whose average incomes lag increasingly behind average house prices. But, as this article will go on to argue, such logic, while not missing the point, does threaten to overlook two very important aspects of the operation of housing markets. The first is that prices are a function of demand of many types - not just that being expressed by ordinary households searching shelter. The second inalienable truth - recognised by housing economists and reality television makers alike - is that location matters, and the housing market cannot adjust itself simply by sloshing supply or demand around from one end of the country to the other. Clearly there are towns and neighbourhoods that are still in need of renewal despite the burgeoning market. 


\section{HMR: a change in emphasis}

While it remains far too early to gauge the long term impacts of Housing Market Renewal, there are clear signs that housing market conditions in the affected areas are improving. The extent to which this can be directly attributable to Pathfinder activity is less certain, and it is true that the general direction and speed of the housing market throughout the country is likely to have had a positive effect.

The language of housing policy has also changed markedly. As was noted earlier, a focus on renewal has arguably ceded to a concern that housing does not unnecessarily impede economic growth and that the housing market does not harm the macroeconomy. This explains a subtle change in emphasis for the HMR agenda and, indeed, plugs it straight into the strategic apparatus of regional economic growth. In turn, this has translated into a changed set of objectives for HMR. How does it contribute to the closure of gaps in economic performance? Take this as a measure of success and suddenly the Pathfinders look like very different places indeed. Manchester and Newcastle-upon-Tyne have booming city-regional economies. Clearly not all of these cities' neighbourhoods are sharing in this success, but that is a different thing to saying that the housing market is generally weak and is holding the economy back. HMR needs a sharper focus in these areas - connectivity at the neighbourhood scale, perhaps - than it does in, say, East Lancashire or in Stoke on Trent.

Yet it is also clear that today's market is qualitatively different to that even a decade ago. Increasing wealth, concerns about pension performance, and a poorly-performing stock market have enhanced the attractiveness of housing as an investment option for individuals and households. Financial deregulation and the wide availability of specialist financial products (such as 'Buy to Let' mortgages) and management services for small lessors have helped to fuel a booming market niche. According to the Council for Mortgage Lenders, there are now nearly one million outstanding Buy to Let mortgages in the UK. The amount of money that has been invested in the sector (£130 billion) since 1999 exceeds CLG and its predecessors' total housing capital investment over the same period ( $£ 31.7$ billion) by a factor of 4.1 (CML 2007; Hansard 24 July 2007) (note CLG figures relate to England only).

The speculative actions of investors, while most closely associated with new city centre developments, have not been confined to new-built properties. While some Pathfinder areas include city centre areas and as such have been particularly affected by the rise in prices that such speculation has brought about, in most Pathfinders it is existing housing in older neighbourhoods that has been the focus of speculation. Sprigings et al. (2006) have noted that the disconnection of prices from incomes and the diversification of purchasers' motivations away from solely 'household consumption' have affected low price markets such as those in Pathfinder areas. The effect has been to contribute to the fear that properties in such areas may have become overvalued. This has in turn raised fears of a bubble, and it would seem logical that the severity of a future downturn in the housing market will be related to any possible 'overvaluation' that Buy to Let and other speculative activity might have contributed to. In such a scenario, it is the properties - and areas - that have been most overvalued that are most at risk of price falls, placing the sustainability of Pathfinders' markets on an unsure footing. 


\section{Conclusion: what next for HMR?}

In terms of market outcomes, it would appear that housing markets in Pathfinder areas are improving. Pathfinders seem broadly on course to deliver the changes that are expected in their local markets. But there remains little in the way of prima facie evidence that Pathfinders have directly contributed to these changes. It is simply too early to tell. The wider context (e.g., the city centre boom and Buy to Let) and policy changes (e.g., Choice Based Lettings) have muddied the picture. More importantly, it is far too early to prejudge whether the significant market changes - price rises, especially - that have been witnessed in Pathfinder areas will be resilient in the face of a general market downturn.

Even over the course of its short life, HMR has seen a shift in its objectives. Originally a clear descendent of an early-New Labour focus on renewal in housing policy, it now occupies a much less comfortable place, struggling to reconcile the new dominant discourse of 'supply' with its local tactical programmes of clearance, reconstruction and new build. The answer lies on more qualitative ground: HMR needs to deliver neighbourhoods with higher quality housing; of the right mix; and in the right places to facilitate a wider economic agenda.

This probably means two things. First, before any judgments as to the role of HMR in the 'new supply paradigm' are rushed into, it may be helpful to have a slightly more speculative take on what has caused signs of positive market outcomes in Pathfinder areas, what constitutes success, and whether sustainable success has been achieved. Buy to Let and macroeconomic change are coincident with these changes: do they provide a sufficiently stable platform for local housing markets should choppier waters be encountered? The second implication has already been touched upon. The strategies of individual HMR Pathfinders will probably need to be much more responsive to local differences than they have been to date. Whilst many of the symptoms look the same, it is clear that some of the causes of the problem in the bigger, resurgent cities are different to those in the poorly-connected, economicallydepressed subregions.

In conclusion there is, as yet, insufficient evidence of precisely what sort of an impact HMR is having. But, more importantly, the resilience of the gains in the face of future market change lies untested. On the basis of available data, it would appear foolhardy to declare 'mission accomplished' at this early juncture. The attendant risks - that local markets weaken and gaps reappear; and that public confidence in regeneration is undermined as promises are broken - appear to suggest that HMR needs to see out what it has started.

* Correspondence Address: Ed Ferrari, Department of Town \& Regional Planning, University of Sheffield, Western Bank, Sheffield, S10 2TN, UK. Email: e.t.ferrari@sheffield.ac.uk.

\section{References}

Audit Commission (2006) Housing Market Renewal Annual Review 2005/06. London: Audit Commission.

Barker, K. (2004) Delivering Stability: Securing our Future Housing Needs. London: HM Treasury. 
Blair, T. (1997) The Will to Win (speech delivered at the Aylesbury Estate, London, 2 June 1997). Available from http://archive.cabinetoffice.gov.uk/seu/newsa52f.html?id=400. Accessed 10 August 2007.

Bramley, G., Pawson, H., Hague, C., Mclntosh, S. and Third, H. (2000) Low Demand Housing and Unpopular Neighbourhoods. London: Department for the Environment, Transport and the Regions.

Burrows, R. and Rhodes, D. (1998) Unpopular Places? Area Disadvantage and the Geography of Misery in England. Bristol: Policy Press.

Cole, I., Kane, S. and Robinson, D. (1999) Changing demand, changing neighbourhoods: the response of social landlords. Sheffield: Centre for Regional Economic and Social Research, Sheffield Hallam University.

Cole, I. and Nevin, B. (2004) The Road to Renewal: The early development of the Housing Market Renewal programme in England. York: Joseph Rowntree Foundation.

CLG (Communities and Local Government) (2007) Homes for the Future: more affordable, more sustainable. Cm 7191. London: The Stationery Office.

CML (Council for Mortgage Lenders) (2007) Buy-to-Let Market Summary. London: Council for Mortgage Lenders. Available from http://www.cml.org.uk/cml/statistics. Accessed 6 September 2007.

DETR (Department for the Environment, Transport and the Regions) (2000) Quality and Choice: A Decent Home for All - the Housing Green Paper. London: Department for the Environment, Transport and the Regions.

DTZ (2007) Sheffield City Centre Housing Market Study. Executive Summary. Sheffield: Sheffield City Council. Available at www.sheffield.gov.uk/index.asp?pgid=113180\&mtype=print $\quad$ (accessed 4 September 2007).

HC 240-I (2002) Empty Homes. Sixth report of the Transport, Local Government and the Regions committee, Session 2001/02. London: The Stationery Office.

Hansard (Commons) 24 July 2007. Column 962W.

HUD (US Department of Housing and Urban Development) (2000) State of the Cities Data Systems (SOCDS). http://socds.huduser.org/socds_home.html. Accessed 5 November 2007.

Holmans, A. E. and Simpson, M. (1999) Low Demand: Separating Fact from Fiction. Coventry: Chartered Institute of Housing.

Jones, C., Leishman, C. and Watkins, C. (2004) Intra-urban migration and housing submarkets: theory and evidence. Housing Studies 19, 2, 269-283.

Keenan, P., Lowe, S. and Spencer, S. (1999) Housing abandonment in inner cities the politics of low demand for housing. Housing Studies 14, 5, 703-716.

Leather, P., Cole, I. and Ferrari, E. (2007) National Evaluation of Housing Market Renewal: Baseline Report. London: Department for Communities and Local Government.

Lee, P. and Murie, A. (1997) Poverty, Housing Tenure and Social Exclusion. Bristol: Policy Press.

Murie, A., Nevin, B. and Leather, P. (1998) Changing Demand and Unpopular Housing. London: The Housing Corporation.

National Housing and Planning Advice Unit (NHPAU) (2007) Affordability Matters. Tichfield, Hampshire: National Housing and Planning Advice Unit. Available from http://www.communities.gov.uk/publications/housing/affordabilitymatters (accessed 4 September 2007).

Nevin, B., Lee, P., Goodson, L., Murie, A. and Phillimore, J. (2000) Changing Housing Markets and Urban Regeneration in the M62 Corridor. Birmingham: Centre for Urban and Regional Studies (CURS), University of Birmingham.

ODPM (Office of the Deputy Prime Minister) (2003) Sustainable Communities: Building for the Future. London: Office of the Deputy Prime Minister. 
ODPM (2005) Homes for All. London: Office of the Deputy Prime Minister.

Pawson, H., Jones, C., Donohoe, T., Netto, G., Fancy, C., Clegg, S. and Thomas, A. (2006) Monitoring the Longer Term Impact of Choice Based Lettings. London: Department for Communities and Local Government.

Pike, A., Champion, T., Coombes, M., Humphrey, L. and Tomaney, J. (2006) The Economic Viability and Self-Containment of Geographical Economies: A Framework for Analysis. London: Office of the Deputy Prime Minister. Available from http://www.communities.gov.uk/documents/corporate/pdf/144515. Accessed 5 September 2007.

Power, A. and Mumford, K. (1999) The slow death of great cities? Urban abandonment or urban renaissance. York: Joseph Rowntree Foundation.

SEU (Social Exclusion Unit) (2001) A New Commitment to Neighbourhood Renewal: National Strategy Action Plan. London: Cabinet Office.

Sprigings, N., Leather, P. and Nevin, B. (2006) Semi-detached housing market theory for sale: suit first time buyer or investor. Paper presented to Conference of the Housing Studies Association, 19-20 April 2006, York.

Turok, I. and Edge, N. (1999) The Jobs Gap in Britain's Cities: Employment Loss and Labour Market Consequences. Bristol: Policy Press.

UTF (Urban Task Force) (1999) Towards an Urban Renaissance. London: E. \& F. N. Spon.

Webster, D. (1998) Employment change, housing abandonment and sustainable development: structural processes and structural issues, In: Lowe, S., Spencer, S. and Keenan, P. (eds.), Housing abandonment in Britain: studies in the cause and effects of low demand housing. York: Centre for Housing Policy, University of York.

Wood, M. and Vamplew, C. (1999) Neighbourhood Images in Teesside: Regeneration or Decline? York: Joseph Rowntree Foundation. 